\title{
Impact of Board of Directors on Performance of Brazilian Banks
}

\author{
Rodolfo Fialho Perondi ${ }^{1}$, Bento Alves da Costa Filho ${ }^{1} \&$ Alcido Elenor Wander ${ }^{2}$ \\ ${ }^{1}$ Master Program in Business Administration, Centro Universitario Alves Faria (UNIALFA), Goiania, GO, Brazil \\ ${ }^{2}$ Master Program in Regional Development, Centro Universitario Alves Faria (UNIALFA), Goiania, GO, Brazil \\ Correspondence: Alcido Elenor Wander, Master Program in Regional Development, Centro Universitario Alves Faria \\ (UNIALFA), Av. Perimetral Norte, 4129, Vila Joao Vaz, 74445-190 Goiania, GO, Brazil. Tel: 55-623-272-5120.
}

Received: December 15, 2020

Accepted: January 29, 2021

Online Published: April 5, 2021

doi:10.5430/ijba.v12n3p42

URL: https://doi.org/10.5430/ijba.v12n3p42

\begin{abstract}
The objective of this paper is to verify if the performance of Brazilian banks was impacted by the characteristics of their boards of directors in the period from 2010 to 2016. Performance indicators were defined as the Return on Assets (ROA) and Return on Equity (ROE) indicators, widely used in bank surveys. To accomplish the objective, a sample of twenty-nine financial institutions registered at the Securities and Exchange Commission (CVM) was selected. Results showed that the variables representing the influences exerted by the board include the number of directors and percentage of female members is significant to explain Return on Assets (ROA), while the variables average age of the directors, the percentage of independent directors, and segregation of the functions of chairman and chief executive officer, are significant in explaining Return on Equity (ROE).
\end{abstract}

Keywords: board of directors, bank governance, performance, independence of the board

\section{JEL Codes: M10, M12, M14}

\section{Introduction}

The Jensen and Meckling (1976) characterization of the agency problem has shown that when an organization is managed not by its "principal" (owner) but by an "agent" (administrator), divergences arise between their desires. While the principal expects the maximum return on his resources, the agent may act within his interests.

Faced with the challenges of reconciling these interests, governance has the role of creating mechanisms and instruments that allow the convergence of the parties' aspirations, this being "means by which resource providers make sure they get a return on their investment" (Shleifer; Vishny 1997, p. 737).

Key elements of corporate governance ensure the creation of a healthy environment and the creation of value to organizations, among which stands out the existence of an effective and independent board of directors, with members external to the corporation; audit council and/or a proactive, active audit committee; and effective risk management (Cardozo, 2005).

It is emphasized that effective action is required by the board of directors, through its "duty of care" and "duty of fidelity", under the applicable national laws and supervisory norms, with active involvement in the main issues of the bank and acting promptly to protect long-term interests of the banks (BIS, 2015).

Bank governance plays an important role in the national economy, as incidents in the financial system can affect the whole economy. Thus, a solid governance structure with effective controls and monitoring, carried out by the board of directors, will result in the efficient allocation of capital and performance of the financial system itself (Levine, 2004).

The relationship between bank governance and economic performance has been studied in the international literature (Liang et al., 2013; Fidanoski et al., 2014; Kramaric and Pervan, 2016; Chou and Buchdadi, 2017; Aslan and Haron, 2020). However, research on this matter in Brazil is not common, which motivates the raise of questions such as how intense the influence of characteristics of Brazilian bank boards is (e.g., independence of directors, number of meetings, the dual position of directors, among others) on economic fulfillment, represented in this study by return on assets and/or return on equity.

Based on the assumption that corporate governance provides an increase in the economic value of the organization 
and improvements in management quality, this paper aims to analyze how corporate governance influences the performance of the banks as companies.

\section{Literature Review}

The conception of the "disintegration of the old atom of property", with new relations between investors, controllers, and administrators (Berle; Means, 1932), characterized by the separation of the areas of control and management, allowed the deepening of discussions on corporate governance (Sonza; Kloeckmer, 2014). The board of directors is the most representative body of this system, as it has overall responsibility, including the approval and supervision of the implementation of strategic objectives, the governance framework, and corporate culture (BIS, 2015).

\subsection{The Role of the Board of Directors}

The board of directors is the most representative element in the corporate governance system since its attributions are to monitor management performance so that shareholders receive an adequate return on their investments; avoid conflicts of interest balancing the competing demands of the organization (Maher and Andersson, 2000).

The Brazilian Institute of Corporate Governance (IBGC) defines the board of directors as a collegiate body responsible for the strategic decision-making process of the organizations acting as a representative of the partners. The council has the responsibility to protect the governance system, as well as the principles and values of the organization (IBGC, 2015).

According to good governance practices, the board's action requires more effort than those defined in the legislation, mainly concerning the quality of the information disclosed and in the results of the organizations. Control activities require "management monitoring and quality reporting for external audiences," and through strategic decisions and management follow-up, "the boards are expected to contribute effectively to improving business performance" (Silveira, 2015, p.149).

For the councils to fulfill all their duties, it is necessary to have independence concerning the administration. Nevertheless, while the emphasis on external systems is on independence, there is a serious problem that, like administration, the board can also become entrenched and fail to fulfill its role (Maher and Andersson, 2000, p. 14).

However, according to the Organization for Economic Co-operation and Development (OECD), "the board should be able to exercise an objective and independent judgment on corporate matters" employing an impartial and objective management approach. Such notes provide care as to the definition of the structure and composition of the councils, safeguarding the existence of a minimum number of independent members (OECD, 2016, p. 58).

\subsection{The Characteristics of Board of Directors and Corporate Performance}

The literature has addressed the theme of corporate governance and its potential to influence or not the performance of companies. However, the significant diversity of approaches and techniques used to verify the relationship between corporate governance and organizational performance was evidenced.

Liang et al. (2013) using a sample of the 50 largest Chinese banks during the 2003-2010 period explored a comprehensive set of board characteristics and analyzed their impacts on banks' performance and the quality of their assets: ROA (Return on Equity), profitability index, pre-provision (operating profit to total assets) and indicators to verify credit quality concerning bank lending practices were used as dependent variables. The independent variables, characteristics of the board of directors included the number of directors; the number of meetings during the year; the dual position of being board and bank chairman; the proportion of independent directors; the proportion of directors politically connected to the board; the proportion of directors acting on three or more boards; and the proportion of directors on the board who are foreigners. Using panel data analysis, it has been found that the number of board meetings and the proportion of independent board members have significantly positive impacts on both bank performance and asset quality, while board size has a significantly negative impact on the performance of the bank.

Fidanoski et al. (2014) verified the relevance of the size, composition of the board, and qualities of the CEO of Macedonian banks concerning their performance. The dependent variables ROA, ROE, efficiency level, and cost of capital adequacy were defined. The independent variables used were: number of Supervisory Board (SB) and Managing Board (MB), percentage of non-executives, foreigners, women, and Ph.D. in the Supervisory Board (SB). Also, dummy variables were defined to verify whether the CEO was a foreigner, bank owner, and had been in the position for more than 4 years. Using the Ordinary Least Squares (OLS) estimation method, 15 banks were analyzed in the period from 2008 to 2011. The main results [verified] showed that the size of the board has a positive relationship with the ROA and that the independence of the board has a negative association with ROA and ROE. Also, it has been found that banks managed by CEOs who hold this position for a longer period are more profitable 
than CEOs in their first four years in office.

Kramaric and Pervan (2016) examined the extent to which the board structure influenced the ROE of the Croatian banks and savings banks in the period from 2002 to 2013. As independent variables, the structure of the board and its supervisory body, the gender of the president, and the number of women members were used. From an econometric model, an unbalanced panel composed of 34 banks was defined. The authors did not document any influence of the chairman's gender on the bank's performance, as well as no influence of the size of the supervisory board on performance.

Chou and Buchdadi (2017), verified the impact of corporate governance variables on the performance of Indonesian banks. Thirty-eight banks were analyzed in the period from 2013 to 2015, which were divided into 2 groups, due to the volume of their assets. With the use of panel data analysis, it was found that the higher the percentage of independent directors, the more intense is the positive impact on the Financial Intermediation Margin (FIM) of the largest banks. Regarding smaller-scale banks, board independence positively impacted banks' market value. The research did not verify the significance between the independence of the council and the ROA. Also, it was found that the percentage of attendance at board meetings is positively related to ROA for small banks and has a positive impact on the FIM for large banks.

Aslan and Haron (2020), used panel data analysis to examine how corporate governance mechanisms affected the ROA and ROE of 129 banks from 29 Islamic countries during the period from 2008 to 2017. The board of directors was analyzed according to board size. If CEO also holds chairman position, and the number of members of non-executive directors, audit committee, risk management committee, Shariah Board. The main findings evidence negative and significant effect the board size and risk management committee on the performance. The number of non-executive directors has a negative and significant relationship with the return on equity and has a positive and significant influence on the return on assets. The findings also suggest that CEO duality, the audit committee and Shariah board (SB) have a positive and significant impact on ROA and ROE.

Therefore, corporate governance has been arousing the interest of researchers, who seek to understand the relationship between organizational performance and the adoption of best practices on the subject. The difficulty in discussing the theme is related to the diversity of variables of performance measurement, as well as in defining which governance indicators should be used in the surveys.

\section{Methodology}

The information used in this research comprises of a panel of annual data of companies registered with the Securities and Exchange Commission of Brazil (CVM), in the "banking" and "financial intermediation" sectors, with registration status in the active condition in more than $80 \%$ of the time, comprised between 2010 and 2016, and which had the data referring to the economic-financial information published on the website of the Central Bank of Brazil (BACEN). Based on the defined characteristics, a sample of 29 banks was obtained.

The definition of the analyzed period was due to the low availability and difficulty in obtaining data related to the topic researched before 2010. The approval of Instructions n. 480 and n. 481, of 2009, by the CVM, required issuers of securities to disclose their economic and financial information in a standardized form, starting in 2010.

In the data collection of the variables, the information systems Economatica was used; Information for economic and financial analysis of the Central Bank of Brazil (BACEN); Reference Form, issued by the Brazilian Securities and Exchange Commission (CVM). The statistical treatment of the data was carried out using the software Gretl Econometric Package, version 2017d; IBM SPSS Statistics, version 23; and Microsoft Excel 2016.

\subsection{Definition of Variables}

According to Tanna et al. (2011), the number of studies related to the impact of corporate governance indicators on banks' performance is relatively lower, compared to those of non-financial corporations. However, the issue has been widely discussed on the international scene.

As defined, it was verified whether the performance of Brazilian banks is related to the characteristics of the structures of the boards of directors. The dependent variables as shown in Table 1, were based on performance indicators Return on Assets (ROA), measuring the profitability on the total assets of the bank and Return on Equity (ROE), measuring the profitability of the shareholders' equity. While the independent variables, shown in Table 2, deal with the characteristics related to the board of directors as follows: (TB) number of members of the board; (CE) the proportion of external directors to the total board; $(\mathrm{CI})$ the percentage of independent directors to the total board members; (CEOIB) dummy variable indicating if CEO is member of the board; (DCEO) dummy indicating if CEO is 
chair of the board; (CM) percentage of females in the board of directors; (MIC) the average age of the counselors; and (NRB) number of annual meetings.

Table 1. Dependent variables

\begin{tabular}{|c|c|c|}
\hline Variable & Description & Authors \\
\hline ROA & $\begin{array}{l}\text { Measures profitability on the total } \\
\text { assets of the company, defined by } \\
\text { the ratio between Net Income and } \\
\text { Total Assets. }\end{array}$ & $\begin{array}{l}\text { Aslam and Haron (2020); Gyamerah et al. (2020); Johan and } \\
\text { Hapsari (2020); Haris et al. (2019); Aktan et al. (2018); AlSagr } \\
\text { et al. (2018); Hajer and Anis (2018); Chou and Buchdadi } \\
\text { (2017); Isik and Ince (2016); Belhaj and Mateus (2016); Bukair } \\
\text { and Rahman (2015); Boussaada and Karmani (2015); Kilic } \\
\text { (2015); Fidanoski et al. (2014); Chaarani (2014); Abdul et al. } \\
\text { (2014); Liang et al. (2013); Pathan and Faff (2013); Adams and } \\
\text { Mehran (2012); Andres and Vallelado (2008); Adams and } \\
\text { Mehran (2008); Bonn et al. (2004). }\end{array}$ \\
\hline ROE & $\begin{array}{l}\text { Measures the profitability of the } \\
\text { company's shareholders 'equity, } \\
\text { defined by the ratio between Net } \\
\text { Income and Shareholders' Equity. }\end{array}$ & $\begin{array}{l}\text { Aslam and Haron (2020); Haris et al. (2019); Aktan et al. } \\
\text { (2018); Handa (2018); AlSagr et al. (2018); Hajer and Anis } \\
\text { (2018); Kramaric and Pervan (2016); Belhaj and Mateus } \\
\text { (2016); Bukair and Rahman (2015); Boussaada and Karmani } \\
\text { (2015); Kilic (2015); Chaarani (2014); Fidanoski et al. (2014); } \\
\text { Liang et al. (2013); Pathan and Faff (2013). }\end{array}$ \\
\hline
\end{tabular}

Source: Authors

Table 2. Independent variables

\begin{tabular}{|c|c|c|}
\hline Variable & Description & Authors \\
\hline TB & $\begin{array}{l}\text { Defined by the number of } \\
\text { members of the board of } \\
\text { directors. }\end{array}$ & $\begin{array}{l}\text { Aslam and Haron (2020); Gyamerah et al. (2020); Haris et al } \\
\text { (2019); Aktan et al. (2018); Handa (2018); AlSagr et al. (2018) } \\
\text { Hajer and Anis (2018); Chou and Buchdadi (2017); Kramaric } \\
\text { and Pervan (2016); Isik and Ince (2016); Belhaj and Mateus } \\
\text { (2016); Bukair and Rahman (2015); Boussaada and Karman } \\
\text { (2015); Kilic (2015); Chaarani (2014); Fidanoski et al. (2014) } \\
\text { Abdul et al. (2014); Liang et al. (2013); Pathan and Faff (2013); } \\
\text { Adams and Mehran (2012); Andres and Vallelado (2008); } \\
\text { Adams and Mehran (2008); Bonn et al. (2004). }\end{array}$ \\
\hline $\mathrm{CE}$ & $\begin{array}{l}\text { Defined by the percentage of } \\
\text { external directors relative to the } \\
\text { total number of board members. }\end{array}$ & $\begin{array}{l}\text { Aslam and Haron (2020); Haris et al. (2019); Isik and Ince } \\
\text { (2016); Belhaj and Mateus (2016); Bukair and Rahman (2015) } \\
\text { Fidanoski et al. (2014); Adams and Mehran (2012); Andres and } \\
\text { Vallelado (2008); Adams and Mehran (2008); Bonn et al } \\
\text { (2004). }\end{array}$ \\
\hline $\mathrm{CI}$ & $\begin{array}{l}\text { Defined by the percentage of } \\
\text { independent directors to the total } \\
\text { number of members of the board } \\
\text { of directors. }\end{array}$ & $\begin{array}{l}\text { Gyamerah et al. (2020); Haris et al. (2019); Aktan et al. (2018) } \\
\text { AlSagr et al. (2018); Chou and Buchdadi (2017); Boussaada } \\
\text { and Karmani (2015); Kilic (2015); Abdul et al. (2014) } \\
\text { Chaarani (2014); Liang et al. (2013); Pathan and Faff (2013) } \\
\text { Adams and Mehran (2012). }\end{array}$ \\
\hline CEOIB & $\begin{array}{l}\text { Dummy variable that equals } 1 \text { if } \\
\text { the CEO is a member of the } \\
\text { board, otherwise zero. }\end{array}$ & Chou and Buchdadi (2017). \\
\hline DCEO & $\begin{array}{l}\text { Dummy variable that equals } 1 \text { if } \\
\text { the CEO also chairs the board of } \\
\text { directors, otherwise zero. }\end{array}$ & $\begin{array}{l}\text { Aslam and Haron (2020); Gyamerah et al. (2020); Aktan et al } \\
\text { (2018); Handa (2018); Hajer and Anis (2018); Chou and } \\
\text { Buchdadi (2017); Belhaj and Mateus (2016); Boussaada and } \\
\text { Karmani (2015); Chaarani (2014); Abdul et al. (2014); Liang et } \\
\text { al. (2013). }\end{array}$ \\
\hline
\end{tabular}


Defined by the percentage of Johan and Hapsari (2020); Handa (2018); Kramaric and Pervan female counselors to the total (2016); Belhaj and Mateus (2016); Kilic (2015); Fidanoski et number of members of the board al. (2014); Liang et al. (2013); Pathan and Faff (2013); Bonn et of directors. al. (2004).

Source: Authors

\subsection{Definition of the Model}

Based on the definition of the number of companies analyzed and the defined time interval, a data panel with 203 observations was created, showing the dependent and independent variables of 29 banks over 7 years, which is characterized as short and unbalanced.

According to Gujarati and Porter (2011, p. 587), the technique of panel data analysis was used, since "the same cross-sectional unit [...] is monitored over time. In summary, panel data has a spatial and temporal dimension."

To test empirically whether the performance of Brazilian banks is related to the structure of boards of directors, two econometric models were preliminarily defined (equations 1 and 2 ).

$$
\begin{aligned}
& R O A_{i, t}=\beta 0+\beta 1 T B_{i, t}+\beta 2 C E_{i, t}+\beta 3 C I_{i, t}+\beta 4 C E O I B_{i, t}+\beta 5 D C E O_{i, t}+\beta 6 C M_{i, t}+\beta 7 M I C_{i, t}+\beta 8 N R B_{i, t}+\varepsilon_{i, t} \\
& R O E_{i, t}=\beta 0+\beta 1 T B_{i, t}+\beta 2 C E_{i, t}+\beta 3 C I_{i, t}+\beta 4 C E O I B_{i, t}+\beta 5 D C E O_{i, t}+\beta 6 C M_{i, t}+\beta 7 M I C_{i, t}+\beta 8 N R B_{i, t}+\varepsilon_{i, t}
\end{aligned}
$$

\section{Results and Discussion}

Based on the methodology described in section 3, the analysis of descriptive statistics, univariate analysis and correlation matrix, robustness tests, model estimation, and results summary were performed in this section.

\subsection{Descriptive Statistics}

The data referring to the variables were summarized in Table 3 , to identify the main information regarding the performance and characteristics of the boards of directors of Brazilian banks.

Table 3. Descriptive statistics of research variables

\begin{tabular}{llllllllllll}
\hline & & ROA & ROE & TB & CE & CI & CEOIB & DCEO & CM & MIC & NRB \\
\hline \multirow{5}{*}{ Average } & 2010 & 3.80 & 21.83 & 6.78 & $85.58 \%$ & $18.22 \%$ & 0.67 & 0.11 & $8.72 \%$ & 55.84 & 9.07 \\
\cline { 2 - 11 } & 2011 & 3.57 & 20.74 & 7.00 & $84.35 \%$ & $21.12 \%$ & 0.64 & 0.11 & $8.65 \%$ & 55.72 & 9.36 \\
\cline { 2 - 11 } & 2012 & 3.19 & 18.99 & 6.76 & $82.61 \%$ & $19.05 \%$ & 0.66 & 0.07 & $9.04 \%$ & 56.53 & 9.14 \\
\cline { 2 - 11 } & 2013 & 2.39 & 14.57 & 6.83 & $81.33 \%$ & $17.47 \%$ & 0.66 & 0.07 & $7.78 \%$ & 56.16 & 9.35 \\
\cline { 2 - 11 } & 2014 & 2.46 & 10.61 & 6.93 & $81.06 \%$ & $17.43 \%$ & 0.69 & 0.10 & $9.40 \%$ & 56.43 & 10.34 \\
\hline \multirow{3}{*}{$\begin{array}{l}\text { Total } \\
\text { Sample }\end{array}$} & 2015 & 1.91 & 11.86 & 6.86 & $79.55 \%$ & $17.20 \%$ & 0.72 & 0.07 & $10.26 \%$ & 56.53 & 10.00 \\
\cline { 2 - 11 } & Average & 2.77 & 15.54 & 6.88 & $81.99 \%$ & $17.97 \%$ & 0.68 & 0.09 & $8.61 \%$ & 56.46 & 9.57 \\
\cline { 2 - 11 } & Medium & 2.24 & 16.64 & 6.00 & $83.33 \%$ & $11.81 \%$ & 1.00 & 0.00 & $0.00 \%$ & 55.80 & 8.00 \\
\cline { 2 - 11 } & Minimum & -2.89 & 18.37 & 2.24 & $13.24 \%$ & $19.54 \%$ & 0.47 & 0.28 & $12.97 \%$ & 7.74 & 5.48 \\
\hline
\end{tabular}

Source: Authors 
The performance measurement was carried on through the Return on Assets (ROA) and Return on Equity (ROE) indexes. It was verified that the mean value of ROA was 2.77 , but the minimum and maximum values were -24.81 and 28.05, respectively. The analysis of the ROE indicator showed an average value of 15.54 , with a minimum and maximum value of -69.88 and 65.58 , respectively. The variation verified between the minimum and maximum values of the indicators, accompanies the results of previous studies, carried out in developing countries, in which it was verified that the oscillation is related to the difference in the size of the banks (Battaglia et al., 2014). Despite the high difference between the ROA and ROE indicators, this is one of the main features of the National Financial System.

The number of members (TB) of the boards of directors of the analyzed banks has an average size close to 7 members, which did not change significantly during the seven years of the sample and follow the IBGC (2015). It should be emphasized that the board of directors must have several members to ensure that they carry out their supervisory role, covering all necessary matters, with sufficient depth and robustness in the discussion of the problems. To do so, it should periodically review its structure, size, and composition, as well as structures and coordination (BIS, 2015, p. 15).

The average number of external directors (CE) in the period studied is over $81 \%$ of the total number of directors. However, according to Figure 1, there was a high tendency to decrease the percentage of participation of external directors (CE), with an $\mathrm{R}^{2}$ of approximately 0.95 .

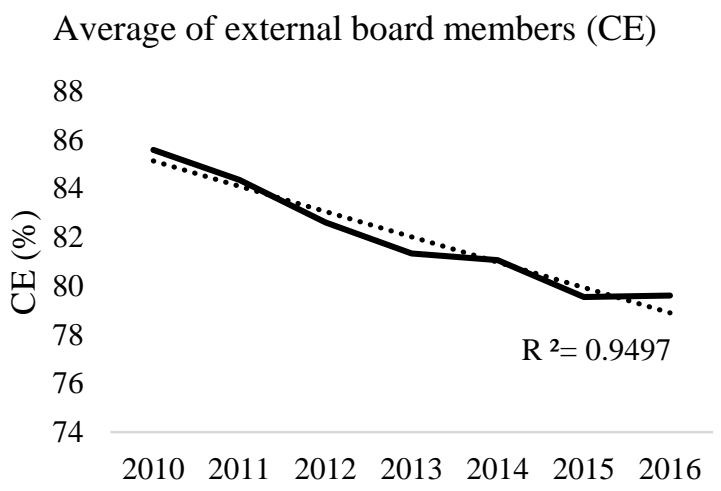

Figure 1. Average variation of external board members (CE)

Source: Authors

Regarding the participation of independent directors (CI), average participation of $17.97 \%$ was verified, as shown in Figure 2, to the total number of directors, contrary to what is recommended in the IBGC (2015) Best Practices Code. Also, there is a downward trend, with an $\mathrm{R}^{2}$ of approximately 0.61 , of the percentage of independent board members.

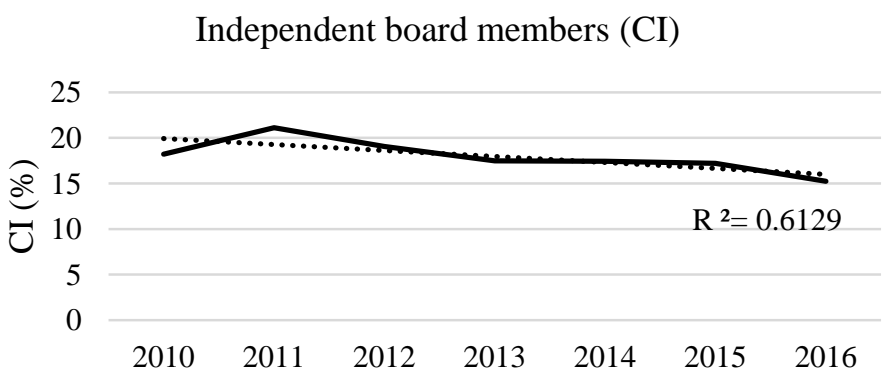

Figure 2. Average variation of independent board members (CI)

Source: Authors 
It should be emphasized that boards need independence from management to fulfill all their responsibilities (Maher and Anderssom, 2010). The OECD (2016) stresses that "the board should be able to exercise objective and independent judgment on corporate matters" and that a minimum number of independent members should be preserved in the structure and composition of the boards (OECD, 2016, p. 58). However, unlike the one defined by the various organizations that address corporate governance, such as the IBGC (2015) and the OECD (2016), there was a reduction in the participation of independent directors $(\mathrm{CI})$ and external directors (CE) on boards of directors during the analyzed period, as well as the tendency to decrease them.

In addition to the independent variables, $\mathrm{CE}$ and $\mathrm{CI}$, two dummy variables were included in the survey, to verify the presence of the CEO as a board member (CEOIB) and the segregation of the duties of chairman and chief executive officer, president (DCEO).

It was verified that the average participation of the CEOs as members of the boards of directors (CEOIB) was 68\%. It was also observed that, in the same period, the average number of functions of president and CEO per one person (DCEO) was $9 \%$.

Despite the advice about the benefits of diversity in the composition of the councils, it was observed that the average participation of women (CM) was less than $9 \%$ of the total membership. It should be noted that despite the increase in discussions in recent years regarding differences in treatment and opportunities between men and women, this fact did not reflect on the composition of the councils.

Regarding the average age of the directors (MIC), the average value of 56.27 years per director was observed, according to data from Table 3. The minimum average age of the council over the considered time was less than 50 years, while the maximum average age was over 70 years.

The average number of meetings of the boards of the banks was 9.57 meetings. However, in some banks, an excessive number of meetings occurred, while in others the number was below the minimum required to guarantee effective performance, as defined by the IBGC.

\subsection{Univariate Analysis and Correlation Matrix}

After the descriptive analysis of the variables, the univariate analysis and the correlation matrix of the variables of the econometric models ROA (3.1) and ROE (3.2) were performed, as shown in Table 4.

A low correlation was verified between the dependent variable ROA and the explanatory variables. Also, the negative relation between ROA and the variables representative of the percentage of external board members (CE), percentage of female members (CM), and the average age of board members (MIC) were observed.

Table 4. Correlation matrix of variables of ROA (3.1) and ROE (3.2) models

\begin{tabular}{|c|c|c|c|c|c|c|c|c|c|c|}
\hline & ROA & ROE & TB & CE & CI & CEOIB & DCEO & $\mathrm{CM}$ & MIC & NRB \\
\hline ROA & 1 & & & & & & & & & \\
\hline ROE & 0.5096 & 1 & & & & & & & & \\
\hline TB & 0.2588 & -0.0317 & 1 & & & & & & & \\
\hline $\mathrm{CE}$ & -0.0438 & 0.0227 & -0.2313 & 1 & & & & & & \\
\hline CI & 0.0095 & -0.1464 & -0.0224 & -0.0898 & 1 & & & & & \\
\hline CEOIB & 0.017 & 0.0966 & 0.4353 & -0.5054 & 0.0435 & 1 & & & & \\
\hline DCEO & -0.0395 & 0.0124 & 0.0321 & -0.3313 & 0.1326 & 0.2094 & 1 & & & \\
\hline $\mathrm{CM}$ & -0.1328 & -0.1229 & -0.0937 & 0.1537 & -0.3492 & -0.1736 & 0.0213 & 1 & & \\
\hline MIC & -0.0767 & -0.1973 & -0.1034 & 0.1025 & 0.1323 & -0.2108 & 01102 & -0.058 & 1 & \\
\hline NRB & 0.0649 & 0.0616 & 0.0918 & 0.0159 & 0.3352 & 0.1764 & -0.1506 & -0.0988 & -0.1525 & 1 \\
\hline
\end{tabular}

Source: Authors

Regarding the ROE dependent variable, there was a low correlation with the explanatory variables. The negative relationship of ROE with the variables related to the total number of members of the council (TB), percentage of 
independent councilors (CI) percentage of female counselors (CM), and the average age of counselors (MIC) was also verified.

The ROA (3.1) and ROE (3.2) models have the same independent variables. The greatest amplitude of correlation between the variables CEOIB and TB, with a coefficient of 0.435, and CEOIB and CE, with a coefficient of 0.505, was verified. However, based on Gujarati and Porter (2011) and Hair et al. (2007), the verified values do not show problems related to multicollinearity.

\subsection{Robustness Test}

After analysis of the descriptive statistics, the univariate analysis and the correlation matrix, the Variance Inflation Factor (VIF), Breusch-Pagan test, Chow test, and the Hausman test were performed.

The Variance Inflation Factor (VIF) test allows the identification of the risk of multicollinearity between the independent variables of the models (3.1) and (3.2), as shown in Table 5.

Following Dantas (2012), VIF values higher than 10 indicate serious problems of multicollinearity. However, the values observed in Table 5 demonstrate the inexistence of multicollinearity problems, since the values are below the established parameter.

Table 5. Variance Inflation Factor (VIF) test results

\begin{tabular}{ll}
\hline Variable & VIF test results \\
\hline TB & 1.251 \\
\hline CE & 1.455 \\
\hline CI & 1.383 \\
\hline CEOIB & 1.719 \\
\hline DCEO & 1.212 \\
\hline CM & 1.206 \\
\hline MIC & 1.126 \\
\hline NRB & 1.289 \\
\hline
\end{tabular}

Source: Authors

The Chow test for models (3.1) and (3.2), define the rejection of the null hypothesis, which disregards individual heterogeneity. This result demonstrates that using the OLS model, is not the appropriate option for the study. Table 6 contains the statistics of the Chow test for the models (3.1) and (3.2).

Table 6. Chow test results for ROA (3.1) and ROE (3.2) models.

\begin{tabular}{lll}
\hline & ROA (3.1) model & ROE (3.2) model \\
\hline Chow test & 4.7597 & 3.2628 \\
\hline Conclusion & $\begin{array}{l}\text { Rejects H0: There is individual } \\
\text { heterogeneity. }\end{array}$ & $\begin{array}{l}\text { Rejects H0: There is individual } \\
\text { heterogeneity. }\end{array}$ \\
\hline
\end{tabular}

Source: Authors

The performance of the Chow test demonstrated that the use of the OLS model was not the appropriate option for the two models, since the regression coefficients differed among the banks surveyed. Based on this finding, it was necessary to include, in the ROA (3.1) and ROE (3.2) models, the variable $C_{i}$, which represents the effect to be estimated of an unobserved variable, which varies among sample banks. With the inclusion of the $C_{i}$ variable, the ROA (3) and ROE (4) models, detailed below, were defined as the basis for the research.

$$
R O A_{i, t}=\beta 0+\beta 1 T B_{i, t}+\beta 2 C E_{i, t}+\beta 3 C I_{i, t}+\beta 4 C E O I B_{i, t}+\beta 5 D C E O_{i, t}+\beta 6 C M_{i, t}+\beta 7 M I C_{i, t}+\beta 8 N R B_{i, t}+
$$




$$
\begin{aligned}
& C_{i}+\varepsilon_{i, t} \\
R O E_{i, t}=\beta 0+\beta 1 T B_{i, t}+\beta 2 C E_{i, t}+\beta 3 C I_{i, t}+ & \beta 4 C E O I B_{i, t}+\beta 5 D C E O_{i, t}+\beta 6 C M_{i, t}+\beta 7 M I C_{i, t}+\beta 8 N R B_{i, t}+ \\
& C_{i}+\varepsilon_{i, t}
\end{aligned}
$$

The results of the Breusch-Pagan test, presented in Table 7, for models (4.1) and (4.2), showed that the residue variance is equal to zero. Thus, with the rejection of the null hypothesis, the model use of random effects is recommended for the analysis of the data of the models (4.1) and (4.2), to the use of the OLS.

Table 7. Breusch-Pagan test results for the ROA (4.1) and ROE (4.2) models

\begin{tabular}{lll}
\hline & ROA (4.1) model & ROE (4.2) model \\
\hline Breusch-Pagan test & 237.8070 & 74.5735 \\
\hline (p-value) & $1.18281 \mathrm{E}-48$ & $\begin{array}{l}5.84221 \mathrm{E}-18 \\
\text { Conclusion }\end{array}$ \\
$\begin{array}{l}\text { Rejects H0: the residue variance is } \\
\text { non-zero. }\end{array}$ & $\begin{array}{l}\text { Rejects H0: the residue variance is } \\
\text { non-zero }\end{array}$
\end{tabular}

Source: Authors

For the definition of the choice between the fixed effect models or random-effects the Hausman test, detailed in Table 8, was performed for the models (4.1) and (4.2). As defined by Hausman (1978), the results observed in the range of 0.00 to 0.01 indicate that the use of the panel with fixed effects is the most suitable.

Following Dantas (2012), it was verified that the test result for the model (4.1) shows that the estimators of the fixed effects and random effects models do not differ substantially, with the use of the panel model with random effects being the most appropriate. In the analysis of the model (4.2) the null hypothesis was rejected, that the estimators of the fixed effects and random effects models do not differ substantially, making use of the model with random effects improper.

Table 8. Hausman test results for ROA (4.1) and ROE (4.2) models

\begin{tabular}{lll}
\hline & ROA (4.1) model & ROE (4.2) model \\
\hline Hausman test & 5.2097 & 28.9357 \\
\hline (p-value) & 0.7349 & 0.0003 \\
\hline Conclusion & $\begin{array}{l}\text { Do not reject H0: Estimators do not differ } \\
\text { substantially. }\end{array}$ & Rejects H0: Estimators differ substantially. \\
\hline
\end{tabular}

Source: Authors

\subsection{Results of Performance Model ROA (4.1)}

Table 9 presents the main results of the empirical test of the analysis of the relationship between the dependent variable ROA, performance proxy, and the independent variables, with the characteristics of the structures of the boards of directors, using the data model in panels with random effects (EA). Also, the results obtained with the ordinary least squares (OLS) and fixed effects (EF) models were presented.

The results showed a high significance, concerning the proposed model, for the variables number of members of the board of directors (TB) and the percentage of female board members (CM). Concerning the others, no significant results were observed. 
Table 9. Estimation results of models for performance variable ROA

\begin{tabular}{|c|c|c|c|c|}
\hline \multirow{2}{*}{ Variable } & \multirow{2}{*}{ Result } & OLS & $\mathrm{EF}$ & EA \\
\hline & & ROA (3.1) & ROA (4.1) & ROA (4.1) \\
\hline \multirow{2}{*}{ const } & Const $(\beta)$ & 3.42613 & -10.258 & -6.63192 \\
\hline & $\mathrm{p}$-value & 0.404 & $0.0816^{*}$ & 0.1949 \\
\hline \multirow{2}{*}{$\mathrm{TB}$} & Const $(\beta)$ & 0.672195 & 0.613786 & 0.622708 \\
\hline & p-value & $0.0001 * * *$ & $0.0395 * *$ & $0.0090 * * *$ \\
\hline \multirow{2}{*}{$\mathrm{CE}$} & Const $(\beta)$ & -0.0141937 & 0.0293591 & 0.0203021 \\
\hline & p-value & 0.6514 & 0.4609 & 0.5601 \\
\hline \multirow{2}{*}{$\mathrm{CI}$} & Const $(\beta)$ & -0.0105643 & 0.00551267 & 0.0020236 \\
\hline & p-value & 0.6079 & 0.8561 & 0.9364 \\
\hline \multirow{2}{*}{ CEOIB } & Const $(\beta)$ & -1.94616 & -0.927911 & -1.06005 \\
\hline & p-value & $0.0427 * *$ & 0.3609 & 0.2523 \\
\hline \multirow{2}{*}{ DCEO } & Const $(\beta)$ & -0.0885388 & -1.34737 & -1.33671 \\
\hline & p-value & 0.9484 & 0.3131 & 0.2655 \\
\hline \multirow{2}{*}{$\mathrm{CM}$} & Const $(\beta)$ & -0.0537734 & -0.0995912 & 0.0888995 \\
\hline & p-value & $0.0631 *$ & $0.0074 * * *$ & $0.0067 * * *$ \\
\hline \multirow{2}{*}{$\mathrm{MIC}$} & Const $(\beta)$ & -0.0466916 & 0.143272 & 0.0909075 \\
\hline & p-value & 0.3181 & $0.0342 * *$ & 0.1171 \\
\hline \multirow{2}{*}{ NRB } & Const $(\beta)$ & 0.0538279 & -0.0188122 & -0.00914842 \\
\hline & p-value & 0.4453 & 0.7814 & 0.8862 \\
\hline Time & & $2010-2016$ & $2010-2016$ & $2010-2016$ \\
\hline Observations & & 197 & 197 & 197 \\
\hline Banks & & 29 & 29 & 29 \\
\hline $\mathrm{R} 2$ & & 0.105806 & 0.740648 & \\
\hline Wald test & p-value & & 0 & \\
\hline Breusch-Pagan test & p-value & & & $1.18281 \mathrm{E}-48$ \\
\hline Hausman test & p-value & & & 0.7349 \\
\hline
\end{tabular}

Notes: *** Significance level of $1 \%$ (p-value <0.01); ** Significance level of 5\% (p-value <0.05); * Significance level of $10 \%$ (p-value $<0.1)$

Source: Authors

The variable representative of the total number of members of the board of directors (TB) positively impacted with a $\beta$ coefficient of 0.622708 , and with a high significance, with a p-value of 0.009 , the ROA model (4.1). Thus, it is shown that boards of directors composed of a larger number of members have a positive impact on Return on Assets (ROA).

In some studies, it was evidenced that the size of the boards significantly and negatively impacted ROA, as in the research carried out by Aslam and Haron (2020), Gyamerah et al. (2020), Boussaada and Karmani (2015), Liang et al. (2013), Pathan and Faff (2013), Bonn et al. (2004). This relationship is justified by the possibility that large boards are more susceptible to inefficiency in the process of coordination, communication, and decision making. However, the result found in this research is in line with the findings of Haris et al. (2019), Aktan et al. (2018), Fidanoski et al. (2014), Adams and Mehran (2012), Abdul et al. (2014), Belhaj and Mateus (2016), Andres and Vallelado (2008), and Isik and Ince (2016), which suggest that the largest number of members assists in decision making, sharing 
knowledge and providing different views.

The percentage of female board members (CM) significantly and negatively impacted the ROA performance proxy. However, despite the high significance, with a p-value of 0.0067 , the observed $\beta$ coefficient was only -0.0888995 .

This relationship was previously investigated by Johan and Hapsari (2020); Handa (2018); Kramaric and Pervan (2016); Belhaj and Mateus (2016); Kilic (2015); Fidanoski et al. (2014); Liang et al. (2013); Pathan and Faff (2013); Bonn et al. (2004). However, only Johan and Hapsari (2020), Kilic (2015) and Fidanoski et al. (2014) showed significance in the studies, which accompany the findings of this research.

According to Simpson et al. (2010), the empirical evidence regarding the ratio of female board members and corporate performance does not provide definitive answers, since the results are developed through different samples and statistical methods. Also, one should consider the nature of the economic factors underlying board selection and board action and methodological problems (Simpsom et al., 2010).

\subsection{Results of Performance Model ROE (4.2)}

Table 10 presents the main results of the relationship between the dependent variable ROE, performance proxy, and the independent variables, using the data model in panels with fixed effects (FE). Also, the results obtained with the ordinary least squares (OLS) and random effects (RE) models were presented.

Table 10. Estimation results of models for performance variable ROE

\begin{tabular}{|c|c|c|c|c|}
\hline \multirow{2}{*}{ Variable } & \multirow{2}{*}{ Resultado } & OLS & FE & $\mathrm{RE}$ \\
\hline & & ROE (3.2) & ROA (4.2) & ROA (4.2) \\
\hline \multirow{2}{*}{ const } & Const $(\beta)$ & 32.8514 & -38.2412 & -5.12680 \\
\hline & p-value & $0.0264 * *$ & 0.1311 & 0.8031 \\
\hline \multirow{2}{*}{$\mathrm{TB}$} & Const $(\beta)$ & -0.823066 & 0.138948 & -0.0622396 \\
\hline & p-value & 0.1787 & 0.9132 & 0.9463 \\
\hline \multirow{2}{*}{$\mathrm{CE}$} & Const $(\beta)$ & 0.144092 & -0.0564094 & 0.0811937 \\
\hline & p-value & 0.2016 & 0.7419 & 0.5711 \\
\hline \multirow{2}{*}{$\mathrm{CI}$} & Const $(\beta)$ & -0.223150 & 0.217405 & -0.0117036 \\
\hline & $\overline{p \text {-value }}$ & $0.0028 * * *$ & $0.098^{*}$ & 0.9077 \\
\hline \multirow{2}{*}{ CEOIB } & Const $(\beta)$ & 3.48466 & -5.32056 & -1.18552 \\
\hline & $\overline{p \text {-value }}$ & 0.3093 & 0.2241 & 0.7628 \\
\hline \multirow{2}{*}{ DCEO } & Const $(\beta)$ & 6.55344 & 10.8932 & 4.5077 \\
\hline & p-value & 0.1828 & $0.0592^{*}$ & 0.3767 \\
\hline \multirow{2}{*}{$\mathrm{CM}$} & Const $(\beta)$ & -0.303135 & -0.0296527 & -0.147893 \\
\hline & $\overline{p \text {-value }}$ & $0.0037 * * *$ & 0.8514 & 0.2752 \\
\hline \multirow{2}{*}{ MIC } & Const $(\beta)$ & -0.404350 & 1.02468 & 0.286498 \\
\hline & p-value & $0.0166^{* *}$ & $0.0005^{* * *}$ & 0.2212 \\
\hline \multirow{2}{*}{ NRB } & Const $(\beta)$ & 0.332269 & -0.119513 & 0.0414983 \\
\hline & p-value & 0.1894 & 0.6821 & 0.8809 \\
\hline Period & & $2010-2016$ & $2010-2016$ & $2010-2016$ \\
\hline Observations & & 197 & 197 & 197 \\
\hline Banks & & 29 & 29 & 29 \\
\hline $\mathrm{R} 2$ & & 0.119884 & 0.631842 & \\
\hline Wald test & p-valor & & 0 & \\
\hline
\end{tabular}




\begin{tabular}{llc}
\hline Breusch-Pagan test & p-valor & $5.84221 \mathrm{E}-18$ \\
\hline Hausman test & p-valor & 0.0003 \\
\hline Sotes: *** Significance level of $1 \%(\mathrm{p}$-value $<0.01) ; * *$ Significance level of 5\% (p-value $<0.05) ; *$ Significance
\end{tabular}

Notes: *** Significance level of $1 \%$ (p-value <0.01); ** Significance level of 5\% (p-value <0.05); * Significance level of $10 \%$ (p-value <0.1)

Source: Authors

The results showed that, with the proposed model, the average age of the board members (MIC), the percentage of independent directors (CI), and segregation of the functions of chairman and chief executive officer (DCEO) were significant. Concerning the other variables, no significant results were observed.

The variable representative of the average age of counselors (MIC) presented a positive relation, with coefficient $\beta$ of 1.02468 , and a high significance, with a value of 0.0005 , due to the ROE model (4.2). This result shows that boards of directors with more experienced members tend to positively influence returns on Shareholders' Equity (ROE).

According to Liang et al. (2013), senior board members may not have the incentive, energy, and knowledge to actively monitor and advise top management, although their research has not found significance in this relationship. Contrary to these arguments, this research showed that more experienced advisors positively impact return on Shareholders' Equity (ROE).

Regarding the variable referring to the percentage of independent board members (CI), a positive relation was observed, with a coefficient $\beta$ of 0.217405 , and significant, with a p-value of 0.098 , with the proposed model. Aktan et al. (2018), Liang et al. (2013) and Pathan and Faff (2013) in their research have noted this relationship as significant and negative, arguing that bank independent advisors are only associated with regulatory compliance and that the availability of high-performance advisors may be limited.

However, the results of this research are in line with Chaarani (2014), who verified a positive and significant relationship between $\mathrm{CI}$ and ROE, since independent board members represent an important line of defense for owners and help in organizational performance, as they are more professional decision-makers and help reduce the opportunism of key executives.

The variable representing the segregation of the functions of chairman and chief executive officer (DCEO) had a significant and positive impact on return on shareholders' equity (ROE), with a p-value of 0.0592 and a coefficient $\beta$ of 10.8932. Despite the positive relationship, this result contradicts the IBGC's (2015) orientation regarding the accumulation of the functions of CEO and chairman of the board by the same person, as there may be a loss in the supervisory function of the executive board. In this sense, Liang et al. (2013) and Chaarani (2014) found a significant and negative relationship between DCEO and ROE, arguing that the CEO's empowerment, by accumulating both functions, may require less use of skills and knowledge, to reduce the performance of banks and increase risk exposure.

\section{Concluding Remarks}

Strengthening financial systems has been one of the biggest challenges in emerging markets and developing economies. In this context, corporate governance has a prominent role, through the promotion of equity, transparency, and corporate responsibility (Battaglia et al., 2014).

In addressing this subject, the main objective of this research was to verify whether the performance of the Brazilian banks is related to its corporate governance structure, analyzed according to the characteristics of the boards of directors. We defined eight independent variables, related to the characteristics of the boards, which were related, through regressions, to the Return on Assets (ROA) and Return on Equity (ROE) variables. The sample was composed of 29 companies, analyzed during the period from 2010 to 2016.

From the above definitions, an unbalanced data panel was composed of 203 observations. The analysis of the descriptive statistics made it possible to highlight the main characteristics of the boards of directors of Brazilian banks. The findings on average showed that the boards have 7 members; $81 \%$ of the board members are external, but only $17.97 \%$ are independent; in $68 \%$ of councils the CEO participates as a member, and in $9 \%$ of the cases he also accumulates the function of chairman of the board; the participation of women is less than $9 \%$ of the total membership; the directors are 56 years old, and councils meet nine times a year.

There was a strong tendency to decrease the average participation of external (CE) and independent (CI) board members on the boards of directors. In this sense, it is emphasized that boards need independence from management 
to fulfill all their functions (Maher and Anderssom, 2010), through "an objective and independent judgment on corporate matters" (OECD, 2016, p. 58).

The first regression was analyzed using the random effects technique, showing that the characteristics of the boards of directors, number of council members (TB), and percentage of female counselors (CM) were statistically significant at the $1 \%$ level to explain the Return on Assets (ROA). As expected, the variable TB presented a positive $\beta$ coefficient. On the other hand, the CM variable presented a negative $\beta$ coefficient, contrary to previously predicted behavior. The other independent variables did not present statistically significant results.

It should be noted that the relationship between the percentage of female counselors (CM) and company performance is difficult to observe since the councils are not yet sufficiently diverse and the percentage of counselors is still incipient (Guerra and Santos, 2017). As verified in this research, the average participation of women in the councils was inferior to $9 \%$, and some councils did not have a feminine presence during certain periods.

According to Fidanoski et al. (2014), diversity implies potential conflicts, as well as a slow decision-making process, which can affect short-term results. However, according to Jensen (2001), and the enlightened stakeholder approach, the maximization of firm value should occur based on the long-term horizon, and discussions are essential for the decision process.

The second regression was analyzed using the fixed effects technique, showing that the characteristics of the boards of directors, the average age of the directors (MIC), the percentage of independent directors (CI), and the segregation of the functions of chairman and chief executive officer (DCEO), were statistically significant, respectively, at the $10 \%, 5 \%$, and $1 \%$ level, to explain the Return on Equity (ROE). The MIC and CI variables presented positive $\beta$ coefficients, as expected. Contrary to the previously predicted behavior, the DCEO variable had a positive $\beta$ coefficient. No statistically significant results were identified for the other independent variables.

The relationship between governance and corporate performance was addressed earlier by several researchers. However, there is still no consensus regarding the approaches and techniques to study the theme. Thus, the results obtained in this research are a relevant source of knowledge to strengthen the understanding of this relationship. Moreover, the results provide academics, investors and legislators with the main characteristics of the structure of boards of directors of Brazilian banks, enabling them to compare with the best market practices, such as the OECD. As an important limitation, it should be emphasized that the results evidenced in this research apply only to the group of studied banks registered at the Securities Exchange Commission of Brazil (CVM), from 2010 to 2016, and which had data referring to the economic and financial information published by Central Bank of Brazil (BACEN). Due to the non-probabilistic character of the sample, the results cannot be generalized.

\section{References}

Abdul Gafoor, C. P., Mariappan, S., \& Thyagarajan, S. (2018). Board characteristics and bank performance in India. IIMB Management Review, 30(2), 160-167. https://doi.org/10.1016/j.iimb.2018.01.007

Adams, R. B., \& Mehran, H. (2008). Corporate performance, board structure and its determinants in the banking industry. FRB of New York Staff Report No. 330. https://doi.org/10.2139/ssrn.1150266

Adams, R. B., \& Mehran, H. (2012). Bank board structure and performance: Evidence for large bank holding companies. Journal of Financial Intermediation, 21(2), 243-267. https://doi.org/10.1016/j.jfi.2011.09.002

Aktan, B., Turen, S., Tvaronavičiené, M., Celik, S., \& Alsadeh, H. A. (2018). Corporate governance and performance of the financial firms in Bahrain. Polish Journal of Management Studies, 17(1), 39-58. https://doi.org/10.17512/pjms.2018.17.1.04

AlSagr, N., Belkhaoui, S., \& Aldosari, A. (2018). The effect of corporate governance mechanisms on bank performance evidence from Saudi banking sector. Asian Economic and Financial Review, 8(8), 1111-1125. https://doi.org/10.18488/journal.aefr.2018.88.1111.1125

Andres, P., \& Vallelado, E. (2008). Corporate governance in banking: The role of the board of directors. Journal of Banking \& Finance, 32, 2570-2580. https://doi.org/10.1016/j.jbankfin.2008.05.008

Aslam, E., \& Haron, R. (2020). Does corporate governance affect the performance of Islamic banks? New insight into Islamic countries. Corporate Governance, 20(6), 1073-1090. https://doi.org/10.1108/CG-11-2019-0350

Bank for International Settlements (BIS). (2015). Corporate governance principles for banks. Retrieved from https://www.bis.org/bcbs/publ/d328.pdf

Battaglia, F., Gallo, A., \& Graziano, A. E. (2014). Strong boards, risk committee and bank performance: evidence 
from India and China. In S. Boubaker, \& D. Nguyen (Eds.), Corporate governance in emerging markets. CSR, Sustainability, Ethics \& Governance. Springer, Berlin, Heidelberg. https://doi.org/10.1007/978-3-642-44955-0_4

Belhaj, S., \& Mateus, C. (2016). Corporate governance impact on bank performance: evidence from Europe. Corporate Ownership \& Control. https://doi.org/10.22495/cocv13i4c4p8

Bonn, I., Yoshikawa, T., \& Phan, P. H. (2004). Effects of board structure on firm performance: A comparison of Japan and Australia. Asian Business and Management, 3(1), 105-125. https://doi.org/10.1057/palgrave.abm.9200068

Boussaada, R., \& Karmani, M. (2015). Did board of directors have an impact on MENA bank performance?. International Journal of Economics and Finance, 7(4), 46-56. https://doi.org/10.5539/ijef.v7n4p46

Bukair, A. A., \& Rahman, A. A. (2015). Bank performance and board of directors' attributes by Islamic banks. International Journal of Islamic and Middle Eastern Finance and Management, 8(3), 291-309. https://doi.org/10.1108/IMEFM-10-2013-0111

Cardozo, J. S. S. (2005). Governança Corporativa: solução, paliativo ou modismo?. Revista de Contabilidade do Mestrado em Ciências Contábeis da UERJ, 10(2), 41-50.

Chaarani, H. E. (2014). The impact of corporate governance on the performance of Lebanese banks. The International Journal of Business and Finance Research, 8(5), 35-46.

Chou, T. K., \& Buchdadi, A. (2017). Independent board, audit committee, risk committee, the meeting attendance level and its impact on the performance: a study of listed banks in Indonesia. International Journal of Business Administration, 8(3), 24-36. https://doi.org/10.5430/ijba.v8n3p24

Dantas, J. A. (2012). Auditoria em instituições financeiras: determinantes de qualidade no mercado brasileiro. Ciências Contábeis - Universidade de Brasília. Doctoral Thesis. Retrieved from http://repositorio.unb.br/bitstream/10482/11751/1/2012_JoseAlvesDantas.pdf

Fidanoski, F., Vesna, M., \& Kiril, S. (2014). Corporate governance and bank performance: evidence from Macedonia. Economic Analysis, 47(1-2), 76-99.

Gil, A. C. (2002). Como elaborar projetos de pesquisa (4th ed.). Sao Paulo: Atlas.

Guerra, S., \& Santos, R. L. (2017). Headaches, concerns, and regrets: what does the experience of 102 Brazilian directors tell us?. International 39. https://www.ifc.org/wps/wcm/connect/6713da75-0339-4cb5-a36b-39de5ab93e45/PSO39.pdf?MOD=AJPERES

Gujarati, D. N., \& Porter, D. C. (2011). Econometria Básica (5th ed.). Porto Alegre: Editora Afiliada.

Gyamerah, S., Amo, H. F., \& Adomako, S. (2020). Corporate governance and the financial performance of commercial banks in Ghana. Journal of Research in Emerging Markets, 2(4), 33-47. https://doi.org/10.30585/jrems.v2i4.541

Hair, J. F. Jr., Babin, B., Money, A. H., \& Samouel, P. (2007). Fundamentos de métodos de pesquisa em administração. Porto Alegre: Bookman.

Hajer, C., \& Anis, J. (2018). Analysis of the impact of governance on bank performance: case of commercial Tunisian banks. Journal of the Knowledge Economy, 9, 871-895. https://doi.org/10.1007/s13132-016-0376-6

Handa, R. (2018). Does corporate governance affect financial performance: a study of select Indian banks. Asian Economic and Financial Review, 8(8), 478-486.

Haris, M., Yao, H., Tariq, G., Javaid, H. M., \& Qurat, U. A. (2019). Corporate governance, political connections, and bank performance. International Journal of Financial Studies, 7(62), 1-37. https://doi.org/10.3390/ijfs7040062

Instituto Brasileiro de Governanca Corporativa. (2015). Código das melhores práticas de governança corporativa (5th ed.). Instituto Brasileiro de Governança Corporativa. - São Paulo, SP: IBGC.

Isik, O., \& Ince, A. R. (2016). Board size, board composition and performance: an investigation on Turkish banks. International Business Research, 9(2), 74-84. https://doi.org/10.5539/ibr.v9n2p74

Jensen, M., \& Meckling, W. (1976). Theory of the firm: managerial behavior, agency costs and ownership structure. Journal of Financial Economics, 3(4), 305-360. https://doi.org/10.1016/0304-405X(76)90026-X

Johan, S., \& Hapsari, C. G. (2020). The gender effect on banking performance in Indonesia. Advances in Economics, 
Business and Management Research, 151, 6-9. https://doi.org/10.2991/aebmr.k.200915.002

Kilic, M. (2015). The effect of board diversity on the performance of banks: evidence from Turkey. International Journal of Business and Management, 10(9), 182-192. https://doi.org/10.5539/ijbm.v10n9p182

Kramaric, P. K., \& Pervan, M. (2016). Does Board Structure Affect the Performance of Croatian Banks?. Journal of Financial Studies \& Research, 2016(2016), 1-10. https://doi.org/10.5171/2016.158535

Levine, R. (2004). The Corporate Governance of Banks - a concise discussion of concepts and evidence, World Bank. Policy Research Working Paper No. 3404, September. Retrieved from https://openknowledge.worldbank.org/handle/10986/14239

Liang, Q., Xu, P., \& Jiraporn, J. (2013). Board characteristics and Chinese bank performance. Journal of Banking \& Finance, 37, 2953-2968. https://doi.org/10.1016/j.jbankfin.2013.04.018

Maher, M., \& Andersson, T. (2000). Corporate governance: effects on firm performance and economic growth. (February, 2000). https://doi.org/10.2139/ssrn.218490

Martins, G. A. (2002). Manual para elaboração de monografias e dissertações (3rd ed.). São Paulo: Atlas.

OCDE (Paris). (2016). G20/OECD principles of corporate governance. https://doi.org/10.1787/9789264259195-pt

Pathan, S., \& Faff, R. (2013). Does board structure in banks really affect their performance?. Journal of Banking \& Finance, 37(5), 1573-1589. https://doi.org/10.1016/j.jbankfin.2012.12.016

Shleifer, A., \& Vishny, R. W. (1997). A survey of corporate governance. The Journal of Finance, 52(2), 737-783. https://doi.org/10.1111/j.1540-6261.1997.tb04820.x

Silveira, A. D. M. (2015). Governança corporativa no Brasil e no mundo: teoria e prática (2nd ed.). Rio de Janeiro: Elsevier.

Simpson, G. S., Carter, D., \& D'Souza, F. P. (2010). What do we know about women on boards?. Journal of Applied Finance, 20(2), 1-13.

Sonza, I. B., \& Kloeckner, G. O. (2014). Does corporate governance influence the efficiency of Brazilian companies?. Revista Contabilidade \& Finanças, $\quad 25(65), \quad$ 145-160. https://doi.org/10.1590/S1519-70772014000200145

Tanna, S., Pasiouras, F., \& Nnadi, M. (2011). The effect of board size and composition on the efficiency of UK banks. International Journal of the Economics of Business, 18(3), 441-462. https://doi.org/10.1080/13571516.2011.618617

Vergara, S. C. (2009). Projetos e relatórios de pesquisa em administração (10th ed.). São Paulo: Atlas.

\section{Copyrights}

Copyright for this article is retained by the author(s), with first publication rights granted to the journal.

This is an open-access article distributed under the terms and conditions of the Creative Commons Attribution license (http://creativecommons.org/licenses/by/4.0/). 